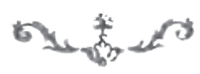

\title{
SPRAWOZDANIE Z KONFERENCJI NAUKOWEJ \\ „ŚWIATY JANA KasprowiCZA" \\ (ZAKOPANE 2016)
}

W DOMU poezji na Harendzie, gdzie spotykają się od zawsze głosy poezji i głosy prozy życia, głosy niecodzienne z głosami codzienności, ślady minionego i corocznie zakwitające na werandzie nasturcje, w czas czerwcowego zmierzchu 2016 roku spotkali się badacze z różnych ośrodków naukowych, żeby przywołać i oswoić światy Jana Kasprowicza. Te poetyckie, zapisane i wyobrażone, te prozatorskie i dramaturgiczne, te związane $\mathrm{z}$ wyborami tłumacza i kłopotami translatologicznymi profesora literatury porównawczej, te domowe i życiowe, te zobrazowane i te projektowane, te doświadczane i te kreowane, te znane i te zapoznane oraz takie, które okazały się świadectwem eksploracji nowych rejonów kasprowiczologii.

Harenda gościła badaczy dziewiętnastowieczności w dniach 25-27 czerwca 2016 roku dzięki uprzejmości organizatora ogólnopolskiej konferencji naukowej „Światy Jana Kasprowicza. W 90-lecie śmierci Poety i 10o-lecie wydania Księgi ubogich" - Stowarzyszenia Przyjaciół Twórczości Jana Kasprowicza. Kasprowiczowska sesja naukowa została objęta patronatem honorowym przez burmistrza miasta Zakopane Leszka Dorulę. Komitet organizacyjny przedsięwzięcia stanowili Karol Jaworski (SPTJK), Małgorzata Karpiel (SPTJK), Anna Podstawka (KUL) i Joanna Zajkowska (UKSW).

Naukowemu spotkaniu ze światami Kasprowicza towarzyszyła prezentacja multimedialna Jan Kasprowicz na tle poezji lat 1864-1894. Prezentacja projektu Narodowego Rozwoju Humanistyki „Poezja na marginesie cywilizacji. Degradacja i odrodzenie twórczości poetyckiej w latach 1864-1894 (podstawa bibliograficzno-materiałowa)". Wyniki badań, kwerend i ustaleń oraz efekty działania multimedialnej bazy bibliograficznej członkowie projektu grantowego zaprezentowali gronu badaczy, bywalcom Harendy i przybyłej na spotkanie Prezes TLiAM Grażynie Borkowskiej. Naukowe dyskusje uwieńczyła promocja ósmego tomu Pism zebranych Jana Kasprowicza. Konferencji towarzyszyła również wystawa Fermenty poznańskie ze zbiorów Jolanty i Mariana Piaseckich. Dzięki zgromadzonej przez 
poznańskich przyjaciół kolekcji białych kruków kasprowiczologii można było dotknąć materii i faktury tekstu i znaku, odczytać unikatowe dedykacje oraz obejrzeć pierwsze wydania dzieł, które zachwycały również szatą ilustracyjną.

Nieocenionym finałem drugiego dnia obrad był koncert na lirę korbową w wykonaniu Macieja Cierlińskiego, Piotra Dąbrowskiego i Natalii Zalewskiej. Koncert „Przynoszę ci kilka pieśni na nutę niewyszukaną” był 175. Wieczorem na Harendzie. Trudno sobie wyobrazić lepsze i bardziej adekwatne zwieńczenie niedzielnych obrad. Kiedy psychodeliczne dźwięki wprowadzały w trans słuchaczy - tych siedzących na podłodze, tych opartych o piec czy siedzących przy łóżku poety i tych zasłuchanych na werandzie czy zaglądających przez okno do wnętrza umuzycznionej izby - na Harendzie pachniało kawą, ciastem, nalewką i starym drewnem. Mieszały się dźwięki, zapachy, szmery i skrzypienie podłogi. Te mięszaniny muzyczno-sensualne, jakbyśmy powiedzieli głosem dziewiętnastowiecznych, roznosiły się po domu Kasprowicza i łagodziły duchy domowego ogniska. Rwanie struktury frazy muzycznej i atonalność niektórych dźwięków oddających istotę Hymnów czy wierszy z Księgi ubogich podkreślały ekspresywną strukturę tekstu poety, gdzie bunt mieszał się z bezsilnością, a chaos świata z perspektywą pogodzenia z trudnym losem. Łagodne przejścia melodii i mollowe tonacje muzycznych pasaży dawały z kolei poczucie spójności i pogodzenia ze światem „ubogiego”, a więc ludzkiego doświadczania księgi świata.

Konferencja naukowa przyniosła wiele nowych możliwości badawczych, zarysowała pola nowych eksploracji, stała się przyczyną ujawnienia zapomnianych meandrów wielopostaciowej i niejednorodnej twórczości autora Chrystusa. Uświadomiła również, że wciąż potrzeba nowych kluczy do otwierania kasprowiczowskich drzwi Harendy i kluczy interpretacyjnych do otwierania światów poety, dramatopisarza, krytyka literackiego, tłumacza, schorowanego starca. Otwarciu konferencji towarzyszyło odczytanie listu nadesłanego przez Romana Lotha (IBL PAN, SPTJK) - edytora twórczości autora Księgi ubogich - który wyraził wdzięczność za zorganizowanie sesji, a także wyraził nadzieję na nowe horyzonty naukowych badań rysujące się dla kasprowiczologii, zapowiedziane przez program sesji.

Tematyka wystąpień była zróżnicowana i trudno określić jej specyfikę czy wyznaczyć osobne kręgi badawcze jako swoiście jednorodne. Dlatego choćby, że w zasadzie każdy prezentowany referat ujawniał skomplikowanie analizowanego problemu, trudność w podejściu do twórczości Kasprowicza, nawet przy założeniu jej wyprofilowania tematycznego i metodologicznego. Wojciech Kaczmarek (KUL) dowodził, na czym polega specyfika i istota poezji Kasprowicza w kontekście współczesnego dyskursu o tożsamości. Badacz ukazywał przejawy trwałości świata poetyckiego autora Hymnów, który nie uległ destrukcji i sytuował namysł poety nad człowiekiem w obrębie szeroko rozumianej myśli chrześcijańskiej i personalizmu. Maria Jolanta Olszewska (UW), dokonując zestawienia poematu Chrystus (189o) z dramatem Świat się kończy (1891), prezentowała tekstowe wyróżniki egzystencjalne i metafizyczne związane z pojmowaniem przez Kasprowicza w jego wczesnej 
twórczości tragedii świata i człowieka. Nieoczywistość spotkania człowieka pytającego o granice i możliwości funkcjonowania w kosmosie zdarzeń po raz kolejny prowokowała do pytania o status podmiotu poznającego rzeczywistość fizykalną i duchową. Urszula M. Pilch (UJ), doskonaląc swój poetologiczny warsztat badawczy, po raz kolejny sięgnęła po próbę opisu kategorii braku, tym razem właśnie w poezji Kasprowicza. Zastosowanie badań związanych z motywiką braku określiło ważny wniosek natury ontologicznej, wyłaniający się z lektury poetyckiej Kasprowicza, że to synekdocha określa brak całości w poezji autora Ksieggi ubogich. Paweł Rams (IBL PAN) mówił o poetyckich zmaganiach z metafizyką zła i udowadniał istnienie Kasprowiczowskich inspiracji w poemacie Teodor Dostojewski Stanisława Brzozowskiego.

Małgorzata Okulicz-Kozaryn (UAM) opowiadała z kolei o współpracy poety z warszawskim „Życiem”. Wnikliwie omawiała nieopublikowany ze względu na skreślenia cenzury cykl $Z$ więzienia, wysłany jako efekt wrażeń więziennych Kasprowicza do Miriamowskiej redakcji „Życia”. Urszula Kowalczuk (UW) pokazywała specyfikę i kompozycję ułożonego przez Kasprowicza Albumu współczesnych poetów polskich: 1863-1898. Badaczka podkreślała znaczenie antologii (i samej poezji) nie tyle służącej celom publicystycznym, ile diagnozie kondycji poezji. Dlatego, stwierdziła, w myśl intencji Kasprowicza, że poezją określa się tu jeden z doniosłych, a niezbywalnych czynników życia społecznego. Radosław Okulicz-Kozaryn (UAM) ujawniał zależność między Kasprowiczem a poznańską Młodą Polską i dowodził znaczenia roku 1894 jako cezury i daty granicznej w myśleniu zarówno o biografii autora Anima lachrymans, jak i istocie ruchu młodopolskiego. Badacz przedstawił wyniki prac dokumentacyjnych i pokazywał swoistą obecność Jana Kasprowicza w „Przeglądzie Poznańskim” Władysława Rabskiego od 1 kwietnia 1894 roku. Joanna Zajkowska (UKSW) zaprezentowała wyniki kwerendy związanej z reprezentatywnością twórczości Kasprowicza w prasie i pokazywała obecność Jana Kasprowicza na łamach „Tygodnika Ilustrowanego”. Katarzyna Kościewicz (UwB) poddawała namysłowi obecność Kasprowicza w kulturze i dydaktyce PRL-u. Badaczka z perspektywy archiwalnej oglądała twórczość poety, poddaną zabiegom cenzury, i określiła zakres zamian, cięć oraz możliwości wydawania Kasprowicza w PRL-u, a także frekwencyjność konkretnych wydań autora Dies irae.

Magdalena Rudkowska (IBL PAN) uświadamiała, na czym mogłaby polegać protomodernistyczność Józefa Ignacego Kraszewskiego, który patronował debiutowi poetyckiemu Kasprowicza, w powiązaniu z różnorodnie widzianymi komponentami twórczymi przyszłego autora Hymnów. Badaczka dostrzegła nieoczywiste sprzężenie na polu artystyczno-intelektualnym Kraszewskiego i Kasprowicza, określające specyfikę ich inkluzywnego i rozłącznego czytania. Marcin Jauksz (UAM) dokonywał modernistycznych remanentów wybranych tekstów Jana Kasprowicza i amerykańskiego pisarza Sherwooda Andersona (1876-1941) oraz pokazywał możliwości ponadintelektulanych i ponadtopograficznych spotkań i podobieństw formalnych oraz tematycznych ich prozy artystycznej. Dawid Maria 
Osiński (UW) dokonał całościowej analizy tłumaczeń Kasprowicza z języka angielskiego i niemieckiego. Pokazywał wybory, decyzje i kłopoty translatora, poddając namysłowi przekłady dokonane w ciągu prawie czterdziestu lat twórczej pracy translatorskiej. Wykorzystywanie narzędzi oferowanych przez współczesną Kasprowiczowi oraz najnowszą szkołę translatologii pozwoliło pokazać oryginalność jego tłumaczeń.

Mirosław Sosnowski (SPTJK), autor monografii o Kasprowiczu, od lat zajmujący się badaniem biograficznych śladów poety, wnikliwie omawiał życio-pisanie Kasprowicza w Zakopanem i pokazywał swoistość tej przestrzeni twórczej dla starego Kasprowicza. Małgorzata Karpiel (SPTJK) oraz Piotr Kyc (SPTJK) interesująco omawiali materialne i niematerialne losy Harendy. Dokonali prezentacji efektów realizacji projektu „Muzeum Jana Kasprowicza na Harendzie, jego zabytki i archiwalia w służbie nauki i kultury", realizowanego przy wsparciu Fundacji PZU w latach 2014-2016.

Wiesław Ratajczak (UAM) dokonał filologicznej, a przy tym określającej ontologiczne wykładniki tekstowe, analizy wierszy o domu w twórczości Kasprowicza. Wielokształtność obrazowania przestrzeń domu i kontekstualność zużytkowania leksemu 'dom' w twórczości poety ujawniała, jak filologia pod piórem autora Ballady o słoneczniku staje się domem egzystencji. I jak język zadomawia pamięć, wyobraźnię i przestrzeń domu wypełnianą smutkiem, ale i ciepłem, który dają najbliżsi. Karol Jaworski (SPTJK) w bogatym dokumentacyjnie i wzruszającym wystąpieniu mówił o Kasprowiczu w domu i o domu Kasprowicza, o poszukiwaniu przez Kasprowicza całe życie miejsca dla siebie i domu, którego synonimem i najważniejszym nośnikiem sensu jest zawsze matka. Dlatego też niestrudzony działacz Harendy i znawca nie tylko dendrologii poetyckiej Kasprowicza, lecz także całej twórczości poety, podkreślał znaczenie wiersza Matka z 1925 roku, powstałego podczas choroby poety. Okazuje się, że Kasprowicz w domu to Kasprowicz w pracy, pracujący nawet wtedy, a może zwłaszcza wtedy, gdy jest cały zagnieżdżony z ludzkiej i domowej codzienności, w krzątaninie, spacerach, myciu, goleniu, czesaniu.

Na prośbę Grzegorza Iglińskiego (UWM) odczytano tekst jego autorstwa. Znawca twórczości Kasprowicza tym razem dał się usłyszeć jako badacz poddający namysłowi figurę św. Genowefy i faunów, co stało się asumptem do analizy Marmuru Kasprowicza w kontekście trwałości prawd i natury ludzkiej. Rozalia Wojkiewicz (UAM), pozostając w duchu od lat prowadzonych badawczych peregrynacji związanych $\mathrm{z}$ witrażowością modernizmu i znaczeniem witrażu jako znaku w kulturze moderny, poddała namysłowi wizerunek średniowiecznego kościoła w twórczości poety. Zwracała uwagę na znaczenie metaforyki romańskiej i gotyckiej w poezji Kasprowicza, a także paronomazyjnej zależności, wyrazistej w tej poezji - okna i oka - będącej transpozycją budującą gotyckość w języku poetyckim Kasprowicza, ale i w całej kulturze modernistycznej eklektyczności.

Anna Podstawka (KUL) pokazywała fascynacje Kasprowicza modernistycznym 
dramatem europejskim od Ibsena do D’Annunzia. Badaczka, idąc tropem skandynawistów - Andrzeja N. Uggli czy ks. Mariana Lewki - pokazywała zupełnie nowe rejony odsłaniające się dla badań nad specyfiką dramatów Kasprowicza, ich możliwościami interpretacyjnymi i polami zależności ze skandynawskim dramatem niepokoju egzystencjalnego i dramatem intymnym. Marek Grajek (UW) próbował odpowiedzieć na pytanie o to, dlaczego pisarz sięga po baśń dramatyczną. Dlatego w tym celu dokonał zestawienia Baśni nocy świętojańskiej Jana Kasprowicza z Dzwonem zatopionym Gerharta Hauptmanna. Magdalena Pawłowska (UW) zajmowała się wykładnikami estetycznymi i etycznymi humoru na przykładzie Misterium tragikomicznego o Marchołcie i pokazywała heterogeniczność świata na opak w wersji kasprowiczowskiej. Wydobywała znaczenie karnawalizacji rzeczywistości odsłaniającej pytania o naturę pewności i niepewności w świecie, a także istoty tragiczności człowieka w rzeczywistości podlegającej nieustannym zmianom. Eliza Kącka (UW) mówiła o zależności i rozłączności parodii i paruzji, żeby zadać pytanie o funkcjonalność parodii w procesie historycznoliterackim (wyznaczając sobie linię diagnozy od Jęku ziemi do Hymnów). Takie ustawienie problemu ujawniało jedne z najważniejszych pytań stawianych tekstom autora Chwil. Pytania te dotyczyły charakteru rekontekstualizacji powrotu do porządku przedustawnego obecnego w poematach Kasprowicza, sensu samego powrotu, który przynosi zawsze różnicę widzenia i poznawania, a także możliwości ogrywania tradycji chrześcijańskiej w poetyce hymnu.

Osobny blok problemowy stanowiły wystąpienia, które dotykały śladów materialnego, sygnatury poety, pisma Kasprowicza czy jego ręki jako ręki malarza. Piotr Kopszak (Muzeum Narodowe w Warszawie) zdał relację z odkrycia rękopisu nieznanego wiersza Kasprowicza zapisanego 3 stycznia 1899 roku w sztambuchu Aleksandra Rajchmana. Sylwia Wyszkowska (ASP w Warszawie) zaprezentowała fotografie przedstawiające rysunki Kasprowicza. Jej wystąpienie przyczyniło się do pytań o kryteria estetyczne i jakość rysunków poety.

Konferencja naukowa Światy Jana Kasprowicza była spotkaniem wielu światów twórczości autora Ciszy wieczornej, wielu horyzontów nakładających się na siebie i odsłaniających nowe możliwości patrzenia w głębię i nie dość zbadaną naturę tekstów poety. Ale w tym patrzeniu i podglądaniu wątków ujawniła nie tylko etapowość samej materii życia i patrzenia na zmienne rytmy doświadczenia prywatnej, intelektualnej biografii uwikłanej w przestrzeń danego regionu, lecz także określiła swoiste ramy różnorodnych trybów i zwrotów topograficznych do oceny etapowości biografii poety, uwikłanej w konkretne miejsce (i zależnej od niego), które wybiera bądź które staje się właśnie jego etapem czy życiową kodą. Naukowe spotkanie z Kasprowiczem i u Kasprowicza przyczyniło się jednak do wypracowania kolejnych kluczy interpretacyjnych do otwierania nowych drzwi światów poety. Do twórczych zbliżeń i oddaleń, szukania śladów i (proto-)zależności artystycznych, splotów artystycznych i węzłów ukrytej dotąd komunikacji międzyzaborowej, śródepokowej, ponadpokoleniowej, a nawet ponadkontynentalnej. Światy Jana 
Kasprowicza - oglądane z perspektywy topiki egzystencjalnej, metafizyki zła i roli manichejskiego widzenia poetyckiej walki światłości z ciemnością, karnawałowości istnienia, splatania się elementów arlekinady i wzniosłości, średniowiecznego kostiumu pomagającego pytać o trwałość i znaczenie śladów religijności czy pytań o sposoby wadzenia się z Bogiem i przyczyny chaosu świata - otwierały na nowo swoje zakamarki. Światy Kasprowicza, wydobyte ze snu, przywołane na nowo do istnienia, wypowiedziane, a więc zadomowione w przestrzeni harendziańskiej chałupy, w głowach referentów i członków Stowarzyszenia Przyjaciół Twórczości Jana Kasprowicza, zmaterializują się niebawem w księdze pokonferencyjnej. Ta zbierze ich niejednorodność i obłaskawi ich obrazy. Może tylko zapomni uchwycić ducha późnoczerwcowego przesilenia kasprowiczowskiego, dobrej wspólnej energii, która gości na Harendzie, kiedy jeździ się tam od kilku lat na grantowe spotkania przyjaciół „poezji na marginesie cywilizacji”. Może zapomni też o wpadających nocą świetlikach i rozciągającej się nad Zakopanem muzyce i śpiewogrom, które nam na werandzie Harendy zawsze towarzyszą, wieńcząc kolejny udany rok akademickich i koleżeńskich spotkań z górami i duchami Marusi i Jana. Jeśli zapomni, przywołamy ten czas i te myśli gdzieś - kiedyś w eterze.

Dawid Maria Osiński 